\title{
Teacher Supervision by Elementary Schools Supervisor through Web-Based Clinical Supervision
}

\author{
Rugaiyah \\ Educational Management \\ Universitas Negeri Jakarta, Indonesia \\ rugaiyah@unj.ac.id \\ Shabrina Amelia \\ Educational Management \\ Universitas Negeri Jakarta, Indonesia \\ shabrinamelia@gmail.com
}

\author{
Siti Nabilah \\ Educational Management \\ Universitas Negeri Jakarta, Indonesia \\ sitinabila22@yahoo.com \\ Desi Rahmawati \\ Educational Management \\ Universitas Negeri Jakarta, Indonesia \\ desimpunj2@gmail.com
}

\author{
Bahrudin \\ Educational Management \\ Universitas Negeri Jakarta, Indonesia \\ bahrudin.unj@gmail.com
}

\begin{abstract}
Many teachers experience difficulties in carrying out teaching-learning activities on the subjects they are teaching. These difficulties can be caused by the characteristics of the subjects taught so that it is difficult for the teacher to understand on those subjects or difficulties in methodological technical aspects so that the instructional material is poorly understood by the students. Clinical supervision by the school supervisor to the teacher is one of the efforts to help the teacher to overcome this problem. This research is intended to provide an overview of the importance of clinical supervision as an alternative solution for teachers and supervisors to enhance and improve the quality of the teaching-learning process, without having to be limited to space and time. This study uses a qualitative approach with descriptive methods. The informants in this study were three supervisors and three teachers. Data collection techniques used for this research are interviews, observation and study of digital documentation. Result of the research show that management and supervision for teacher conducted by supervisor through web-based clinical supervision can be effectively implemented, since the supervisor can provide inputs and solutions for every problem to enhance the teaching-learning process. Those supervision can contribute to the achievement of the objective of the education.
\end{abstract}

Keywords: school supervisor, teacher management and supervisory, web based clinical supervision

\section{INTRODUCTION}

The teacher is a human resource that must be continuously nurtured and developed. Potential teachers gradually grow and develop in order to be able to function optimally. Besides, the effects of rapid change encourage teachers to continue to adapt to the development of science and technology and community mobility. Teacher supervision is very important to improve teacher performance in the teaching-learning process. Many teachers have difficulties to deliver subjects they should taught. These difficulties can be caused by the characteristics of the subjects so that it is difficult for teachers to understand or difficulties in the technical methodological aspects so that teaching materials are not understood by students. Clinical supervision conducted by school supervisors for teachers is one of the efforts to assist teachers to overcome the problems they are experiencing. A study shows that clinical supervision can assist teachers to find out their weaknesses and strengths in teaching in the classroom and assist teachers to improve the learning process to be more effective (Veloo, et al, 2013).
Recently, most of the supervision that has been taken based on the initiative of the supervisor and the principal, not from the teacher himself. Ideally, all efforts and initiative to improve the quality of learning should come from teachers who have problems. The initiative to improve teaching skills which coming from the teacher itself is very important to be developed, since it is the core of the concept of clinical supervision. Other studies show that by carrying out clinical supervision, reflective learning occurs where teachers practice intelligent thinking in analyzing complex situations to understood and develop meaning and gain a deeper understanding of experiences in the learning process (Dewey in Sharrock, et al. 2012).

The rapid pace of technological development contributes to a number of activities carried out by anyone including members of the education unit. The technology developed at this time requires supervisors, principals and teachers to continuously update their knowledge to support supervisory or supervision activities to run more effectively and efficiently. The internet makes it easy for anyone to do the desired activity without having to go to 
the relevant place first. This allows supervisors to control or guide teachers in one-click.

The next obstacle experienced by supervisors when they want to supervise teachers is to set a schedule for meeting. The teacher already has a lot of work to do at school, so it is difficult to find some time to have a face to face session with the supervisor. The number of schools that must be supervised is also in several different places, while one supervisor must supervise a minimum of 60 teachers.

The use of the latest technology is also still a disabling factor in the implementation of clinical supervision for number of teachers who do not understand or are unable to follow the steps given in the use of the technology. With the application of clinical supervision, it is expected that clinical supervision activities more effective and efficient. The results showed that clinical supervision carried out through face-to-face was not felt to be able to provide optimal results. A study conducted by Olson (2008) shows that clinical supervision assisted by the use of technology has proven to be more effective, including: facilitating the supervision process even though the location is far or in remote area and minimizing costs or efficient.

\section{METHOD}

Based on the research topic, the specific purpose of this study is to describe in detail regarding the teacher's supervision carried out by supervisors through web-based clinical supervision. This research uses a qualitative approach with descriptive methods. Qualitative research is a research method that is based on the philosophy of positivism, used to examine the natural conditions of objects where the researcher is become a key instrument, also where data collection techniques are carried out by triangulation (combined), and more emphasis on the meaning rather than the generalization. The data in this study are resulted from observations and interviews conducted during the process of collecting data in the field also desk study of documents.

Data analysis in this study was carried out at the time the data collection took place and after data collection was completed. The data analysis technique uses a model developed by Miles and Huberman in the form of stages: data reduction in which the researcher summarizes, chooses the main information, focuses on the important things, looks for themes and patterns, discards unnecessary data and information with the aim of facilitating the researcher collects further data. The second stage is data display in the form of a brief description, charts, and relationships between categories to facilitate the planning of further work. The next stage is data verification involves testing the provisional conclusions, carrying out the re-checking process, and making general conclusions.

\section{RESULT AND DISCUSSION}

Web-based clinical supervision by elementary school supervisor is carried out through several stages, namely preparation, collaborative analysis, and feedback conferences. Preparation for clinical supervision begins with opening the website www.supervisiklinis.com through any web browsers. Then the teacher must input the required documents on the supervision website. The things prepared by the teacher include lesson plans, syllabus, learning videos, internet connections, as well as adequate gadgets. From the supervisor's point of view, the supervisor only needs to look at the availability of adequate internet networks and gadgets where the supervisor will conduct web-based clinical supervision.

The next step to do is collaborative analysis. The collaborative analysis is done after the teacher inputs the documents, and the submission of clinical supervision is received by the supervisor through the website. At this stage, the supervisor conducts an evaluation syllabus, lesson plans, and supervision of learning videos. Supervisors do not need to bring or prepare an assessment instrument because it is already available on the website. Furthermore, supervisors conduct a feedback conference or face to face with the teacher in an agreed place, it can be in the school where the teacher is teaching or the supervisor's office, but the space used must be conducive so that the supervisor and teacher can communicate calmly and comfortably. The supervisor then conveys the things that have been observed in the collaborative analysis process.

In this web-based clinical supervision activity, the teacher conveys what obstacles he experiences in the learning process through the website. Supervisors who have the responsibility in improving the quality of school educations, which become their target have a role in helping to find a problem solving. Forms of teacher development are carried out through input provided by supervisors to teachers to improve the teaching and learning process. Web-based clinical supervision is done in the long term so that coaching can contribute to the achievement of educational goals.

The implementation of web-based clinical supervision is sequentially carried out and follows the mechanism of its implementation. First, the preparatory phase includes setting the schedule between the supervisors and the teachers which are done after the teachers have submitted the documents on the website. The obstacles encountered when teachers rarely submit to the web-based clinical supervision to supervisors in each target schools so that the implications for the assessment process cannot be done.

Second, the collaborative analysis phase of webbased clinical supervision where supervisors assess syllabus, lesson plans, and video supervision of learning in the classroom. Supervisors observe and examine the documents that have been inputted by uploading them first through the website and making an assessment. Obstacles that occur in the process of collaborative analysis such as unstable internet networks or supervisors do not remember the instructions that must be followed when using the website. This process has implications for the evaluation of the assessment made by the supervisors as an assessor in identifying weaknesses and analyzing teacher potential.

Third, at the stage of the web-based clinical supervision feedback conference, supervisors and teachers meet at the agreed place and time to discuss the reports on the results of syllabus scores, lesson plans, and 
supervision of instructional videos. The implementation of web-based clinical supervision is a form of coaching conducted by supervisors in the context of improving the quality of learning. Coaching is collaboratively done between teachers and supervisors so that the results of coaching through this web-based clinical supervision become more effective and efficient.

\section{CONCLUSION}

The implementation of web-based clinical supervision is sequentially carried out and follows the mechanism of its implementation. First, the preparatory phase includes setting the schedule between the supervisors and the teachers which are done after the teachers have submitted the documents on the website. Second, the collaborative analysis phase of web-based clinical supervision where supervisors assess syllabus, lesson plans, and video supervision of learning in the classroom. Third, at the stage of the web-based clinical supervision feedback conference, supervisors and teachers meet at the agreed place and time to discuss the reports on the results of syllabus scores, lesson plans, and supervision of instructional videos.

\section{REFERENCES}

[1] Gursoy, E. Clinical Supervision Model to Improve Supervisory Skills of Cooperating Teachers and University Supervisors During Teaching Practice. (2013).

[2] Prosper, M. Teacher Supervision and The Concept of Clinical Supervision. Sciences Sociales Et Humaines. (2006). 209-216.

[3] Fteiha, A., \& Abdawi, N. The Effectiveness of Clinical Supervision on Technology Teacher's Professional Development in Jerusalem A Case Study. The Eurasia Proceedings of Educational and Social Sciences (2017). 17.

[4] Shmelev, A. G. Psychodiagnosis of Personnel Characteristics. Sait-Peterburg. (2002).

[5] Glickman, C. D., Gordon, S. P., and Ross. J. M. Supervision and Instructional Leadership: a development approach. (2001). 